\title{
IPS DALAM PENDEKATAN KONSTRUKTIVISME (STUDI KASUS PADA KEBUDAYAAN JAWA)
}

\author{
Tutik Wijayanti ${ }^{\circledR}$, Saka Mahardika Oktav ${ }^{2}$, Fitria Martanti ${ }^{3}$, Muh. Sholeh \\ 1,2,3,4 Pascasarjana, Universitas Negeri Semarang
}

Info Artikel

Sejarah Artikel:

Disubmit: Oktober 2021

Direvisi: November 2021

Diterima: Novemebr

2021

Keywords:

Pendidikan; Pendidikan

IPS; Konstruktivisme;

Suku Jawa.

\begin{abstract}
Abstrak
Ilmu Pengetahuan Sosial memiliki dimensi keilmuan yang sangat luas. Ruang lingkup IPS adalah kehidupan sosial manusia di masyarakat. Oleh karena itu, masyarakat inilah yang menjadi sumber utama IPS. Aspek kehidupan sosial apapun yang kita pelajari, apakah itu hubungan sosial, ekonomi, budaya, kejiwaan, sejarah, geografi, ataupun politik, bersumber dari masyarakat. Sehingga dibutuhkan suatu pendekatan filsafat yang akan memberikan suatu pembelajaran yang modern tidak konvensional seperti pendekatan konstruktivisme. Metode yang digunakan dalam penelitian ini ialah metode studi kepusatakaan. Penelitian ini bermuara pada temuan bahwa guru tidak lagi menduduki tempat sebagai satu-satunya pemberi ilmu. Tidak lagi sebagai satu-satunya sumber belajar. Namun guru lebih diposisikan sebagai fasiltator yang memfasilitasi siswa untuk dapat belajar dan mengkonstruksi pengetahuannya sendiri. Mendasarkan pengamatan pada kearifan lokal dan kebudayaan Suku Jawa, penggabungan pembelajaran IPS yang menggunakan pendekatan konstruktivisme diharapkan mampu menjadikan peserta didik menjadi warga negara yang demokratis, bertanggung jawab, serta warga dunia yang cinta damai.
\end{abstract}

\section{Abstract}

Social Sciences have a very broad scientific dimension. The scope of social studies is human social life in society. Therefore, this community is the main source of IPS. Whatever aspect of social life we study, whether it be social relations, economics, culture, psychology, history, geography, or politics, comes from society. So, we need a philosophical approach that will provide modern, unconventional learning such as the constructivism approach. The method used in this research is the library study method. This research leads to the finding that teachers are no longer the only providers of knowledge. No longer the only source of learning. However, the teacher is positioned more as a facilitator who facilitates students to be able to learn and construct their knowledge. Based on observations on local wisdom and Javanese culture, the incorporation of social studies learning using a constructivist approach is expected to be able to make students democratic, responsible, and peaceful citizens of the world.

(C) 2021 Universitas Negeri Semarang

\footnotetext{
Alamat korespondensi:

ISSN 2252-7133

Gedung C4, Lantai 1, Program Studi PPKn FIS UNNES

E-ISSN 2548-4648

Kampus Sekaran, Gunungpati, Semarang, 50229

E-mail: tutikwijayanti@mail.unnes.ac.id
} 


\section{PENDAHULUAN}

Pembelajaran yang diidentikkan dengan kata "mengajar" berasal dari kata dasar "ajar" yang berarti petunjuk yang diberikan kepada orang supaya diketahui (diturut) ditambah dengan awalan "pe" dan akhiran "an menjadi "pembelajaran", yang berarti proses, perbuatan, cara mengajar atau mengajarkan sehingga anak didik mau belajar (Retnoningsih, 2009). Pembelajaran menurut Syaiful (Zain, 2003) merupakan proses komunikasi dua arah, mengajar dilakukan oleh pihak guru sebagai pendidik, sedangkan belajar dilakukan oleh peserta didik atau murid. Hal yang sama juga dikemukakan Dimyati dan Mudjiono (Mudjiono, 2006) pembelajaran adalah kegiatan guru secara terprogram dalam desain instruksional, untuk membuat siswa belajar secara aktif, yang menekankan pada penyediaan sumber belajar.

Dari beberapa Pengertian Pembelajaran di atas, dapat ditarik kesimpulan mengenai pembelajaran, bahwa pembelajaran adalah proses interaksi peserta didik dengan pendidik. Pembelajaran merupakan bantuan yang diberikan pendidik agar dapat terjadi proses pentrasferan ilmu dan pengetahuan, penguasaan kemahiran dan tabiat, serta pembentukan sikap dan kepercayaan pada peserta didik. Dengan kata lain, pembelajaran adalah proses untuk membantu peserta didik agar dapat belajar dengan baik.

Dalam pembelajaran IPS sebagai salah satu komponen programatik di dalam kurikulum sekolah, sesungguhnya banyak diharapkan untuk mendukung tercapainya tujuan ideal pendidikan. Stanley (1986:7) di dalam mengantar buletin NCSS no. 75 berjudul "Review of Research in Social Studies Education 1976-1983", juga berpandangan bahwa "sungguhpun semua matapelajaran di sekolah bernilai atau berharga bagi anak, akan tetapi tidak ada yang lebih mendasar dan lebih penting daripada pendidikan IPS". Akan tetapi kelemahan kurikulum dan kemampuan mengemas serta mengembangkan materi, tampaknya tidak hanya ditemukan pada guru. Menurut Mulder paradigma yang digunakan oleh para penulis dalam menyusun dan mengorganisasi materi, cenderung bernuansa "ideologis". Artinya, senantiasa memposisikan negara sebagai institusi yang "monolitis", menguasai dan melingkupi individu dan masyarakat. Masalah- masalah sosial pun direduksi menjadi sebatas persoalan individu dan masyarakat. Akibatnya kata Mulder, materi-materi tersebut tidak membantu siswa untuk belajar berpikir kritis dan reflektif tentang kehidupan bermasyarakat secara demokratis.

Selain itu sebagian besar siswa tidak tertarik terhadap pelajaran IPS yang terlihat dari ekspresi jenuh, bosan, dan bersikap pasif dalam menerima pelajaran. Sikap tidak senang menerima pelajaran IPS juga disebabkan karena penyajiannya lebih banyak memuat aspek kognitif dan terpusat pada hafalan, dan guru juga tidak mampu mengemas materi yang dapat mengembangkan kemampuan siswa berpikir kreatif, objektif dan logis. Akibatnya, pelajaran IPS lebih memberi kesan sebagai pelajaran hafalan yang membosankan dan kurang membangkitkan motivasi siswa untuk giat belajar, yang akhirnya mempengaruhi perolehan hasil belajar mereka.

Indonesia merupakan sebuah bangsa yang begitu besar dan terdiri atas berbagai macam budaya di dalamnya (Marnelly, 2018). Berbicara mengenai budaya, Supian, dkk. (2017) mengatakan bahwa budaya adalah suatu pandangan hidup yang dimiliki bersama oleh sekelompok organisasi, dimana hal tersebut merupakan warisan yang diberikan oleh generasi terdahulu kepada generasi selanjutnya yang dapat berubah-ubah sesuai perkembangan waktu. Banyaknya berbagai macam agama, suku, maupun budaya yang ada di Indonesia merupakan keistimewaan yang menjadikan bangsa Indonesia unik untuk dipandang oleh bangsa lain. Etnis Jawa sendiri merupakan etnis terbesar di Indonesia dengan jumlah 95,2 juta $(40,2 \%)$ dari seluruh penduduk Indonesia (Na'im dan Syaputra, 2010). Jumlah etnis Jawa yang sangat besar tersebut tersebar di seluruh wilayah Indonesia (Adelina, dkk, 2017). 
Berdasarkan berbagai persoalan diatas, dari paradigma "Mainstream Academic Knowledge" ke paradigma "Transformative Academic Knowledge" (Banks, 1995), maka pembelajaran IPS perlu direkonstruksi sejalan dengan perkembangan paradigma pendidikan mutakhir, yakni konstruktivisme. Selain itu dengan pembelajaran yang monoton dan lebih bersifat menghafal maka penulis ingin memasukkan materi IPS terhadap budaya Jawa, yang nantinya output dari pembelajaran IPS dapat memberikan hasil yang optimal. Maka rumusan masalah yang ingin dibahas dalam artikel ini adalah "IPS Dalam Pendekatan Konstruktivisme (Studi Kasus pada Kebudayaan Jawa)“. Serta tujuan dari penulisan ini adalah untuk meningkatkan upaya mutu belajar pada peserta didik melalui pembelajaran IPS dengan menggunakan pendekatan konstruktivisme.

\section{METODE PENELITIAN}

Metode yang digunakan dalam penulisan artikel ini ialah metode studi kepustakaan. Metode studi kepustakaan dilakukan dengan mengumpulkan informasi dan data secara mendalam melalui berbagai literatur seperti artikel ilmiah, buku, catatan, majalah, referensi lainnya, serta hasil penelitian sebelumnya yang relevan untuk mendapatkan jawaban dan landasan teori mengenai masalah yang akan diteliti. Dalam penelitian ini, prosedur studi kepustakaan dilakukan dengan pemilihan topik, ekplorasi informasi seputar pendidikan IPS, pendekatan konstruktivisme, dan kebudayaan Jawa. Setelah menentukan fokus penelitian, peneliti melakukan pengumpulan data dari berbagai sumber data, melakukan pencatatan, dan penyusunan laporan hingga penyusunan artikel.

\section{HASIL DAN PEMBAHASAN}

\section{Pengertian IPS dan Hakikat Pendidikan IPS}

Ilmu Pengetahuan Sosial merupakan terjemahan dari social studies. Bahwa social studies merupakan ilmu-ilmu sosial yang disederhanakan untuk tujuan pendidikan meliputi aspek-aspek ilumu sejarah, ilmu ekonomi, ilmu politik, sosiologi, antropologi, psikologi, ilmu geografi dan filsafat yang dalam prakteknya dipilih untuk tujuan pembelajaran disekolah dan perguruan tinggi.

Dalam buku Toni, dkk. (Lubis, 2018) bahwa pengertian social studies mengandung hal-hal sebagai berikut.

1. Social studies merupakan turunan dari ilmu-ilmu sosial.

2. Disiplin ini dikembangkan untuk memenuhi tujuan pendidikan pada tingkat persekolahan maupun tingkat perguruan tinggi.

3. Aspek-aspek dari masing-masing disiplin ilmu sosial itu perlu diseleksi sesuai dengan tujuan tersebut.

Rumusan tentang pengertian IPS telah banyak dikemukakan oleh para ahli IPS atau Social Studies. Berikut pengertian IPS yang dikemukakan oleh beberapa ahli berikut.

1. Menurut Soemantri, IPS adalah pelajaran ilmuilmu sosial yang disederhanakan untuk pendidikan tingkat SD, SLTP, dan SLTA. Penyederhanaan disini mengandung arti menurunkan tingkat kesukaran ilmu-ilmu sosial yang biasanya dipelajari di universitas menjadi pelajaran yang sesuai dengan kematangan berfikir siswa siswi sekolah dasar dan lanjutan, dan mempertautkan serta memadukan bahan aneka cabang ilmu-ilmu sosial dan kehidupan masyarakat sehingga menjadi pelajaran yang mudah dicerna.

2. Menurut Moeljono Cokrodikardjo, IPS adalah perwujudan suatu pendekatan interdisipliner dari ilmu sosial. IPS ini merupakan integrasi dari berbagai cabang ilmu sosial yakni sosiologi, antropologi, budaya, psikologi, sejarah, geografi, ekonomi, ilmu politik dan ekologi manusia, yang diformulasikan untuk tujuan instruksional dengan materi dan tujuan yang disederhanakan agar mudah dipelajari.

Sedangkan rumusan tentang pengertian pendidikan IPS juga telah banyak dikemukakan oleh para ahli, yakni:

1. Menurut Sapriya (2007), Pendidikan IPS adalah penyederhanaan atau adaptasi dari disiplin ilmu- 
ilmu sosial dan humonaria, serta kegiatan dasar manusia yang di organisasikan dan disajikan secara ilmiah dan pedagogis/psikologis untuk tujuan pendidikan.

2. Menurut Soemantri (2001), Pendidikan IPS adalah penyederhanaan adaptasi, seleksi dan modifikasi dari disiplin akademis ilmu-ilmu sosial yang diorganisasikan dan di sajikan secara ilmiah dan pedagogis-psikologis untuk tujuan institusional pendidikan dasar dan menengah dalam dalam kerangka mewujudkan tujuan pendidikan nasional yang berdasarkan pancasila.

Dengan demikian, IPS adalah pelajaran ilmu sosial dan pendidikan IPS dilaksanakan baik pada pendidikan dasar maupun pada pendidikan tinggi yang tidak menekankan pada aspek teoritis keilmuannya, tetapi aspek praktis dalam mempelajari, menelaah, mengkaji gejala, dan masalah sosial masyarakat, yang bobot dan keluasannya disesuaikan dengan jenjang pendidikan masing-masing.

IPS sebagai mata pelajaran ditingkat pendidikan dasar hingga perguruan tinggi pada hakikatnya bersifat terpadu yang merupakan penyederhanaan, penyesuaian, seleksi, dan modifikasi dari kosep-konsep dan keterampilan-keterampilan disiplin ilmu sejarah, geografi, sosiologi, antropologi, ekonomi yang diorganisasikan secara ilmiah dan psikologis untuk tujuan pembelajaran. Rumpun ilmu IPS seperti sejarah, geografi dan antropologi mempunyai keterpaduan yang erat. Sejarah memberikan pengetahuan mengenai kejadiankejadian dari berbagai periode. Geografi memberikan kebulatan wawasan yang berhubungan dengan daerah-daerah. Sementara itu, antropologi berkaitan dengan nilai-nilai, kepercayaan, struktur sosial, kegiatan-kegiatan ekonomi, organisasi politik, teknologi, dan budaya.

\section{Pembelajaran IPS dan Pendekatan Konstruktivisme}

Konstruktivisme berasal dari kata konstruktiv dan isme. Konstruktiv berarti bersifat membina, memperbaiki, dan membangun. Sedangkan Isme dalam kamus Bahasa Inonesia berarti paham atau aliran. Konstruktivisme merupakan aliran filsafat pengetahuan yang menekankan bahwa pengetahuan kita merupakan hasil konstruksi kita sendiri (von Glaserfeld dalam Suparno 1997:18) Pandangan konstruktivis dalam pembelajaran mengatakan bahwa anak-anak diberi kesempatan agar menggunakan strateginya sendiri dalam belajar secara sadar, sedangkan guru yang membimbing siswa ke tingkat pengetahuan yang lebih tinggi (Slavin, 1995). Teori yang melandasi pendekatan konstruktivis dalam pembelajaran IPS yaitu teori perkembangan kognitif Piaget dan teori perkembangan fungsi mental Vygotsky. Piaget menyatakan bahwa anak membangun sendiri skemanya serta membangun konsep-konsep melalui pengalaman-pengalamannya.

Jadi teori konstruktivisme adalah suatu proses pembelajaran yang mengkondisikan siswa untuk melakukan proses aktif membangun konsep baru, pengertian baru, dan pengetahuan baru berdasarkan data. Oleh karena itu proses pembelajaran harus dirancang dan dikelola sedemikian rupa sehingga mampu mendorong siswa untuk mengorganisasi pengalamannya sendiri menjadi pengetahuan yang bermakna. Teori ini mencerminkan siswa memiliki kebebasan berpikir yang bersifat eklektik, artinya siswa dapat memanfaatkan teknik belajar apapun asal tujuan belajar dapat tercapai.

Konstruktivisme dalam Pendidikan diharapkan siswa memiliki kebebasan berpikir yang bersifat eklektik, artinya siswa dapat memanfaatkan teknik belajar apapun asal tujuan belajar dapat tercapai. Bermaksud agar menjadikan anak didik memiliki kualitas dengan memanfaatkan teknik belajar apapun. Selain itu guru disini mempunyai peran sebagai mediator dan fasilitator untuk membantu agar proses belajar siswa berjalan dengan baik. Maka disini siswa yang belajar dengan bebas guru hanya membimbing. Praktik dalam pendidikan menerapkan serangkaian kegiatan berupa implementasi kurikulum dan interaksi antara guru dengan peserta didik guna mencapai tujuan pendidikan dengan menggunakan rambu- 
rambu dari teori-teori pendidikan. agar pendidikan di negara ini memiliki arah yang jelas dan tepat.

Dalam pembelajaran pendekatan konstruktivis lebih aktif dan kreatif, pengajar memberikan kegiatankegiatan yang merangsang keingintahuan siswa, membantu mereka untuk mengekspresikan gagasan mereka dan mengkomunikasikan ide-idenya. Dalam sistem konstruktivis guru dituntut penguasaan bahan yang luas dan mendalam. Guru perlu mempunyai pandangan yang sangat luas mengenai pengetahuan dari bahan yang mau diajarkan. Pendekatan konstruktivis menekankan pentingnya interaksi sosial dan negosiasi dalam pembelajaran. Dalam praktik kelas, pendekatan konstruktivis mendukung kurikulum dan pengajaran student center bukannya teacher center. Proses belajar lebih penting daripada hasilnya. Pembelajaran menjadi lebih bermakna.

Dalam mata pelajaran IPS adalah salah satu jembatan yang akan menghubungkan tujuan dari filsafat konstruktivisme. Yang mana pendidikan IPS merupakan suatu mata pelajaran yang kompleks yang dalam tujuannya adalah untuk mengembangkan pengetahuan sikap dan keterampilan sosial dilingkungan peserta didik. Dengan kerangka berpikir di atas bisa diyakini bahwa pendekatan konstruktivisme perlu diintegrasikan dalam pembelajaran IPS di kelas. Tujuannya adalah untuk dapat memberikan hasil belajar IPS yang lebih bermakna dalam pengembangan life skill siswa berkaitan dengan kemampuan sosialnya bila dibandingkan dengan pendekatan yang konvensional, seperti pendekatan behavioristik, yang selama ini diterapkan di sekolah.

Pendekatan pembelajaran IPS berbasis kearifan local yang salah satunya dapat dimasukkan kedalam materi sejarah Jawa merupakan salah satu contoh penerapan pembelajaran konstruktivis, dan dapat diterapkan dalam pembelajaran IPS. Dengan pendekatan pembelajaran ini, tidak saja siswa dapat mengembangkan konsep-konsep sendiri dalam memecahkan masalah-masalah sosial dalam kehidupan bermasyarakat, mengembangkan kepekaan terhadap masalah-masalah sosial di lingkungannya, mengembangkan prosedur berpikir ilmiah, meningkatkan rasa percaya diri, dan mengembangkan keterampilan-keterampilan sosial dalam ikut serta meningkatkan partisipasi sosial sebagai warga negara yang baik, bernalar, dan bertanggung jawab. Dengan demikian Tujuan pembelajaran IPS dalam konstruktivisme adalah diharapkan agar peserta didik menjadi warga negara yang demokratis, bertanggung jawab, serta warga dunia yang cinta damai.

\section{Pembelajaran IPS dan Pendekatan Konstruktivisme dalam Perspektif Kebudayaan Jawa}

Kebudayaan Jawa merupakan salah satu kebudayaan paling dominan di Indonesia. Suryadinata et al. (2003) menjelaskan, Suku Jawa merupakan suku terbesar di Indonesia yang berasal dari Jawa Tengah, Jawa Timur, Daerah Istimewa Yogyakarta, Kabupaten Indramayu, Kabupaten/Kota Cirebon (Jawa Barat) dan Kabupaten/Kota Serang - Cilegon (Banten). Pada tahun 2010, setidaknya 40,22\% penduduk Indonesia merupakan etnis Jawa. Selain itu, suku Jawa ada pula yang berada di negara Kaledonia Baru, Oseania dan Suriname, Amerika Selatan. Hal ini karena pada masa kolonial Belanda, suku Jawa dibawa ke sana sebagai pekerja. Saat ini suku Jawa di Suriname menjadi salah satu suku terbesar di sana dan dikenal sebagai Jawa Suriname.

Melalui dominasi mayoritas tersebut, suku Jawa memiliki corak kebudayaan yang sangat beragam. Budaya Jawa secara garis besar dapat dibagi menjadi 3 yaitu budaya Banyumasan, budaya Jawa Tengah-DIY, dan budaya Jawa Timur. Budaya Jawa mengutamakan keseimbangan, keselarasan dan keserasian dalam kehidupan sehari-hari. Budaya Jawa menjunjung tinggi kesopanan dan kesederhanaan. Budaya Jawa termasuk salah satu budaya di Indonesia yang paling banyak diminati di luar negeri. Beberapa budaya Jawa yang diminati di luar negeri adalah Wayang kulit, Keris, Batik, Kebaya, dan Gamelan. Di Malaysia dan Filipina dikenal istilah keris karena pengaruh Majapahit. 
Fakta lainnya ialah LSM Kampung Halaman dari Yogyakarta yang menggunakan wayang remaja dan menjadi LSM Asia pertama yang menerima penghargaan seni dari Amerika Serikat tahun 2011. Gamelan Jawa juga menjadi pelajaran wajib di AS, Singapura, dan Selandia Baru. Gamelan Jawa rutin digelar di AS dan Eropa atas permintaan warga AS dan Eropa. Dalam bidang kesastraan, Sastra Jawa Negarakretagama menjadi satu satunya karya sastra Indonesia yang diakui UNESCO sebagai Memori Dunia. Menurut Guru Besar Arkeologi Asia Tenggara Universitas Nasional Singapura John N. Miksic, hal tersebut terjadi karena jangkauan kekuasaan Majapahit meliputi Sumatra dan Singapura, bahkan Thailand yang dibuktikan dengan pengaruh kebudayaan, corak bangunan, candi, patung, dan seni.

Budaya Jawa termasuk unik karena membagi tingkat bahasa Jawa menjadi beberapa tingkat yaitu Ngoko, Madya, dan Krama. Ada yang berpendapat budaya Jawa identik feodal dan sinkretik. Pendapat itu kurang tepat karena budaya feodal ada di semua negara termasuk Eropa. Budaya Jawa menghargai semua agama dan pluralitas sehingga dinilai sinkretik oleh budaya tertentu yang hanya mengakui satu agama tertentu dan sektarian.

Kaberagaman tersebut tentu menjadi sumber dan modal pembelajaran yang besar bagi pendidikan di Indonesia terutama bagi keilmuan sosial. Hal ini karena laboratorium pembelajaran bagi rumpun sosial ialah masyarakat dengan beragam atribut dar. kebudayaannya. Pada titik ini, pendidikan IPS memiliki peranan penting dalam melestarikan kebudayaan dan kearifan lokal tersebut. Melalui pendekatan konstruktivisme, siswa sebagai individu aktif membangun pengetahuannya sendiri tentang kebudayaan Jawa. Hal ini dilakukan dengan cara mengalami dan mengerjakannya, dalam keseharian secara terus-menerus, sehingga fakta dan keterampilan dipelajari secara holistik dan terjadi proses menghubungkan pengetahuan dan keterampilan tentang kebudayaan Jawa ke dalam pengetahuan dan keterampilan yang telah dimiliki sebelumnya.
Dalam perspektif nilai, pembelajaran IPS yang mengedepankan sopan santun dan tata aturan sejalan dengan kebudayaan yang dianut oleh masyarakat Jawa. Nilai-nilai ini berkembang menjadi falsafah hidup dalam masyarakatnya. Pendekatan konstruktivisme yang digunakan pun menjadi fasilitator dalam mengejawantahkan nilai kebudayaan Jawa pada mata pelajaran Ilmu Pengetahuan Sosial di satuan pendidikan.

\section{SIMPULAN}

Ruang lingkup IPS adalah kehidupan sosial manusia di masyarakat. Oleh karena itu, masyarakat inilah yang menjadi sumber utama IPS. Aspek kehidupan sosial apapun yang kita pelajari, apakah itu hubungan sosial, ekonomi, budaya, kejiwaan, sejarah, geografi, ataupu politik, bersumber dari masyarakat. Pendekatan konstruktivisme, guru disini tidak lagi menduduki tempat sebagai pemberi ilmu. Tidak lagi sebagai satu-satunya sumber belajar. Namun guru lebih diposisikan sebagai fasiltator yang memfasilitasi siswa untuk dapat belajar dan mengkonstruksi pengetahuannya sendiri. Mendasarkan pengamatan pada kearifan lokal dan kebudayaan Suku Jawa, penggabungan pembelajaran IPS yang menggunakan pendekatan konstruktivisme diharapkan mampu menjadikan peserta didik menjadi warga negara yang demokratis, bertanggung jawab, serta warga dunia yang cinta damai.

\section{DAFTAR PUSTAKA}

Adelina, F., Hanurawan, F., \& Suhanti, I. Y. (2017). Hubungan antara prasangka sosial dan intensi melakukan diskriminasi mahasiswa etnis Jawa terhadap mahasiswa yang berasal dari Nusa Tenggara Timur. Jurnal Sains Psikologi, 6(1), 18.

Banks, J. A. (1995). The historical reconstruction of knowledge about race: Implications for transformative teaching. Educational researcher, 24(2), 15-25.

Lubis, T. N. (2018). Konsep Dasar Ilmu Pengetahuan Sosial. Yogyakarta: Samudra Biru. 
Marnelly, T. R. (2018). Dinamika Sosial Budaya Masyarakat Melayu Pesisir (Studi Pengelolaan Madu Sialang di Desa Rawa Mekar Jaya). Jurnal Antropologi: Isu-Isu Sosial Budaya, 19(2), 149-154.

Mudjiono, D. d. (2006). Belajar dan Pembelajaran. Jakarta: Rineka Cipta.

Na'im dan Syaputra. 2011. Kewarganegaraan, Suku, Bangsa, Agama, dan Bahasa Sehari-hari Penduduk Indonesia: Hasil Sensus Penduduk 2010. Jakarta: Badan Pusat Statistik.

Retnoningsih, S. \&. (2009). Kamus Besar Bahasa Indonesia. semarang: Widya Karya.

Sapriya. (2007). Pendidikan IPS. Bandung: Remaja Rosdakarya.

Slavin, R. E. (1995). Cooperative learning. Theory, Research and Practice. Second edition. Boston: Allyn and Bacon.
Soemantri, N. (2001). Menggagas Pembaharuan Pendidikan IPS. Bandung: Rosdakarya.

Stanley, B. G., Kyrkouli, S. E., Lampert, S., \& Leibowitz, S. F. (1986). Neuropeptide Y chronically injected into the hypothalamus: a powerful neurochemical inducer of hyperphagia and obesity. Peptides, 7(6), 11891192.

Suparno, P. (1997). Filsafat konstruktivisme dalam pendidikan. Yogyakarta: Kanisius, 12-16.

Supian, Y. (2017). Integrasi ilmu pengetahuan dan teknologi pada pembelajaran Pendidikan Agama Islam: Studi di SMAN 2 Padalarang Bandung Barat (Doctoral dissertation, UIN Sunan Gunung Djati Bandung).

Suryadinata, L., Arifin, E. N., \& Ananta, A. (2003). Indonesia's population. ISEAS Publishing.

Zain, S. B. (2003). Strategi Belajar Mengajar. Jakarta: Rineka Cipta. 